\title{
Spatial variation in directional swimming enables juvenile sea turtles to reach and remain in productive waters
}

\author{
F. Christiansen ${ }^{1,2, *}$, N. F. Putman ${ }^{3,4}$, R. Farman ${ }^{5}$, D. M. Parker ${ }^{6}$, M. R. Rice ${ }^{7}$, \\ J. J. Polovina ${ }^{8}$, G. H. Balazs ${ }^{8}$, G. C. Hays ${ }^{1}$ \\ ${ }^{1}$ Deakin University, Geelong. Centre for Integrative Ecology, School of Life and Environmental Sciences, \\ Warrnambool Campus, VIC 3280, Australia \\ ${ }^{2}$ Cetacean Research Unit, School of Veterinary and Life Sciences, Murdoch University, Murdoch, WA 6150, Australia \\ ${ }^{3}$ Cooperative Institute for Marine and Atmospheric Studies, Rosenstiel School for Marine and Atmospheric Science, \\ University of Miami, 4600 Rickenbacker Causeway, Miami, FL 33149, USA \\ ${ }^{4}$ Atlantic Oceanographic and Meteorological Laboratory, National Oceanic and Atmospheric Administration, \\ 4301 Rickenbacker Causeway, Miami, FL 33149, USA \\ ${ }^{5}$ Aquarium des Lagons, B.P. 8185, Nouméa 98807, Nouvelle-Calédonie \\ ${ }^{6}$ Joint Institute for Marine and Atmospheric Research, University of Hawaii, 2032 SE Oregon State University Drive, \\ Newport, Oregon 97365, USA \\ ${ }^{7}$ Hawaii Preparatory Academy, 65-1692 Kohala Mountain Road, Kamuela, Hawaii 96743, USA \\ ${ }^{8}$ Pacific Islands Fisheries Science Center, National Marine Fisheries Service, \\ National Oceanic and Atmospheric Administration, 2570 Dole Street, Honolulu, Hawaii 96822, USA
}

\begin{abstract}
Ocean currents play an important role in the movement and distribution of organisms and for small animals it is often assumed that their movements in the ocean are determined by passive drift. Here we challenge this assumption by conducting an experiment at the scale of an entire ocean basin to test whether small $(\sim 35 \mathrm{~cm})$ juvenile loggerhead sea turtles Caretta caretta move independently of ocean currents. By comparing the trajectories of 46 satellite tracked turtles (11502 positions, 12850 tracking days) with Lagrangian drifters (3 716303 positions, 927529 tracking days) and virtual particles tracked within the Hybrid Coordinate Ocean Model (HYCOM), we found that in certain areas turtles moved in a similar manner to ocean currents, but in other areas turtle movement was markedly different from ocean currents, with turtles moving to areas thousands of kilometres from where they would have drifted passively. We further found that turtles were distributed in more-productive areas than would be expected if their movement depended on passive transport only. These findings demonstrate that regional variation in directional swimming contributes to young sea turtles reaching more favourable developmental habitats and supports laboratory work suggesting that young turtles have a map sense to determine their location in a seemingly featureless ocean.
\end{abstract}

KEY WORDS: Animal tracking $\cdot$ Caretta caretta $\cdot$ HYCOM $\cdot$ Lagrangian drifters $\cdot$ Movement ecology $\cdot$ Ocean currents

\section{INTRODUCTION}

Many animal species show impressive long-distance movement (Wehner 2003, Hein et al. 2012, Hays \& Scott 2013), which allows them to make use of spatiotemporal variations in resource availability

\footnotetext{
*Corresponding author: f.christiansen@murdoch.edu.au
}

to maximize fitness (Alerstam et al. 2003, Dingle \& Drake 2007, Putman et al. 2014). When the movement of animals is affected by flows in the medium through which they journey (e.g. water and air), many animal species can identify flow-related displacement and adjust their movement accordingly

() The authors 2016. Open Access under Creative Commons by Attribution Licence. Use, distribution and reproduction are unrestricted. Authors and original publication must be credited. 
(Alerstam et al. 2003, Åkesson \& Hedenström 2007, Dingle \& Drake 2007, Chapman et al. 2011, Putman \& Mansfield 2015). This ability often varies with ontogeny, as the ratio between flow strength and the animals' own ability of movement changes with age and/or size (Chapman et al. 2011). While adults of many species seem able to compensate partially or fully for flows, younger age classes are thought to be less capable of doing so and environmentally induced drift is thought to primarily account for directional movement (Hays et al. 2010, Chapman et al. 2011).

With the ability to undertake long-distance movement in open oceans (Luschi et al. 2003), sea turtles represent a model species with which to study the ontogeny of movement in relation to ocean flows. Adult turtles possess remarkable navigational abilities, possibly using a combination of the earth's geomagnetic field (Luschi et al. 2007) and olfactory cues (Hays et al. 2003), to travel from hundreds to thousands of kilometres between breeding and foraging sites (Luschi et al. 2003, Hays \& Scott 2013, Hays et al. 2014). In contrast, it has long been thought that young sea turtles, because of their limited swimming and diving abilities coupled with positive buoyancy, drift passively with ocean currents (Luschi et al. 2003, Hays et al. 2010). A recent tracking experiment calls this hypothesis into question, showing that small turtles significantly diverge from simultaneously deployed drifters (designed to track currents at the ocean surface) in a matter of days (Putman \& Mansfield 2015). Model simulations further show that directional swimming is necessary for young sea turtles (i.e. hatchlings) to remain within favourable ocean currents (Scott et al. 2012), and for ensuring self-recruitment in physically open marine systems (Wolanski 2016). Likewise, a growing number of laboratory experiments indicate that hatchling loggerhead sea turtles Caretta caretta perceive both latitudinal and longitudinal information from components of the Earth's geomagnetic field and show directional swimming that could help them reach and/or maintain their position in favourable ocean areas (Lohmann \& Lohmann 1994, Lohmann et al. 2001, 2004, Putman et al. 2011).

Whether an animal swims actively or drifts passively in the ocean will be determined not only by its physiological abilities, but also by what potential benefits a particular movement strategy will bring. Interestingly, not all magnetic fields that exist within the oceanic range of loggerheads elicit robust orientation responses. For example, hatchling turtles exposed to magnetic fields that correspond to productive ocean regions were randomly oriented (Putman et al. 2015). Presumably, highly directional swimming in response to magnetic fields in such regions would not be strongly selected for, as quickly transiting through such areas is unlikely to be beneficial (Putman et al. 2015). Simulating this spatially variable orientation behaviour observed under laboratory conditions leads turtles into productive areas favourable for development (Putman et al. 2012, 2015), however, whether or not this occurs in the wild is not known. Further, while satellite-tracked juvenile turtles have been found to aggregate in more productive waters (Polovina et al. 2006, Abecassis et al. 2013), whether they actively swim to these areas or are passively carried there by ocean currents, is unknown.

The aim of this study is to extend our knowledge of directional swimming in juvenile sea turtles in the wild, by investigating long-term ( $>1 \mathrm{yr}$ ) tracking data of free-living juvenile loggerhead turtles across an entire ocean basin. To do this, we capitalize on the miniaturization of satellite tags that allow small turtles to be tracked remotely (Kobayashi et al. 2014, Scott et al. 2014). We also develop novel analytical methods to test the main hypotheses of juvenile turtle movement derived from laboratory and modelling studies: that directional movement by turtles (1) broadly varies by region and (2) facilitates movement into more favourable ocean habitats than would be expected if directional movement exclusively depended on ocean currents (Lohmann et al. 2012, Putman et al. 2012, 2015, Mansfield \& Putman 2013). We address these questions by comparing actual tracks of juvenile loggerheads with passive drift scenarios, using Lagrangian drifters and the Hybrid Coordinate Ocean Model (HYCOM).

\section{MATERIALS AND METHODS}

\section{Turtle data}

We satellite-tagged 46 juvenile loggerhead turtles and released them into the open ocean $367 \mathrm{~km}$ southwest of New Caledonia $\left(24.98^{\circ} \mathrm{S}, 163.03^{\circ} \mathrm{E}\right)$ in the western Pacific (Fig. 1a) on 21 September 2012 in $1250 \mathrm{~m}$ deep water with a temperature of $20.7^{\circ} \mathrm{C}$ (see Table S1 in Supplement 1 at www.int-res.com/ articles/suppl/m557p247_supp/). The turtles were hatched and raised, for the purpose of this study, at the Aquarium des Lagons in Noumea, New Caledonia, from eggs collected from multiple excavated nests from beaches in New Caledonia. The turtles were 1 yr 7 mo old at the time of release. Upon 
release their mean $\pm \mathrm{SD}$ straight carapace length was $34.8 \pm 2.7 \mathrm{~cm}(\min .=31.0, \max .=41.0 \mathrm{~cm})$ and their weight $6.2 \pm 1.2 \mathrm{~kg}(\min .=4.0, \max .=9.1 \mathrm{~kg})$ (Table 1 in Supplement 1). The turtles were tracked using Smart Position or Temperature (SPOT5) satellite transmitting nano-tags developed by Wildlife Computers (wildlifecomputers.com). The SPOT5 tags were attached to the turtle's carapace using epoxy resin and fiberglass cloth. The tags use the Argos satellite network for geopositioning and were programmed with a $6 / 42$ transmission duty cycle ( $6 \mathrm{~h}$ on, $42 \mathrm{~h}$ off, per $48 \mathrm{~h}$ interval). Each nano-tag weighed $48 \mathrm{~g}$, which was between 0.5 and $1.2 \%$ of the weight of the turtles. The Argos system assigns each calculated position with a specified level of accuracy. We reconstructed the tracks of the turtles using all good-quality locations (location classes 1-3, errors $<1500 \mathrm{~m}$ radius, see www.argos-system.org) while excluding poor-quality locations (location classes A, $\mathrm{B}, 0$ and Z). We also processed the data through a speed filter, which removed all positions that would have required a swim speed $>5 \mathrm{~m} \mathrm{~s}^{-1}$ ( $\mathrm{n}=341$ positions or $2.9 \%$ of all positions). This threshold was chosen based on the distribution of swim speeds.

\section{Ocean currents}

Movement tracks from passively moving Atlantic Oceanographic \& Meteorological Laboratory (AOML) Lagrangian drifters were obtained from the NOAA Global Drifter Program, which is freely available (www.aoml.noaa.gov/phod/dac/index.php). The drifters consist of a small surface buoy attached to a subsurface drogue (sea anchor) that is centred at $15 \mathrm{~m}$ below the surface. With oceanic juvenile loggerhead turtles spending most of their time $(90 \%)$ in this upper $15 \mathrm{~m}$ layer (Howell et al. 2010), the Lagrangian drifter data should be representative of the ocean currents that are most likely to influence turtle movement (Howell et al. 2010). To obtain a sufficiently large drifter dataset to cover the area traversed by the turtles (Fig. 1a), we downloaded drifter data from 1980 to 2013 (data were available until June 30, 2013). Although the drifters transmit their position between 16 and 20 times per day, the drifter data are provided in an interpolated format with a $6 \mathrm{~h}$ temporal resolution. To maximize spatial coverage in the region where turtles were tracked and account for physical processes that might influence turtle movement at the ocean surface (e.g. Stoke's drift, windage), we also included data from Lagrangian drifters which had lost their sea anchor.
Modelled ocean velocity was based upon surface currents of the Global Hybrid Coordinate Ocean Model (HYCOM) (Bleck 2002). Global HYCOM has output at 00:00 h GMT with a spatial resolution of $0.08^{\circ}(\sim 7 \mathrm{~km}$ grid-spacing at mid-latitudes). The model is forced using wind stress, wind speed, heat flux, precipitation, and river runoff. Hindcast output assimilates satellite altimetry data, sea surface temperature, and in situ measurements from XBTs (expendable bathythermographs), Argo floats, and moored buoys (http://hycom.org). Thus, HYCOM hindcasts accurately resolve mesoscale features such as meandering currents, fronts, filaments and oceanic eddies (Bleck 2002, Chassignet et al. 2007) and realistically characterize the movement of passively drifting objects at the ocean surface (Putman \& He 2013). HYCOM output was taken for the period from 21 September 2012 through 25 December 2013, the same time-span over which turtles were tracked.

\section{In silico trajectories}

Model simulations were used to compare the movement of turtles, drifters and HYCOM particles. The study area $\left(\mathrm{Lat}_{\min }=60^{\circ} \mathrm{S}, \mathrm{Lat}_{\max }=0^{\circ} \mathrm{S}\right.$, Long $_{\min }=$ $120^{\circ} \mathrm{E}$, Long $_{\max }=140^{\circ} \mathrm{W}$ ) (Fig. 1a) was first divided into 6000 grid cells of size $1^{\circ} \times 1^{\circ}$. A contingency table (similar to van Sebille 2014), representing all possible transitions (i.e. movements) between grid cells in the study area, was created. Each turtle track was binned into an array of grid cells, and the number of transitions between different grid cells was added to the contingency table. From the resulting contingency table we estimated the proportion of time that turtles moved from a specific grid cell to another in the study area (by scaling the values in a row so that they sum to 1). For grid cells that were never visited by a turtle, all the transition values were set to 0 . To conform to the same temporal resolution as the Lagrangian drifter dataset, we first interpolated our turtle data to a $6 \mathrm{~h}$ temporal resolution based on linear interpolation. Thus, each cell in the turtle transition matrix represented the probability of a turtle moving from one grid cell to another over the next $6 \mathrm{~h}$. The same procedure was performed using the tracks of the Lagrangian drifter buoys that passed through the study area between 1980 and 2013. We thus ended up with 2 transition probability matrices, one for the turtles, and one for the drifters, with the same temporal resolution.

Based on the estimated transition probability matrices, we simulated the trajectories of 1000 turtle par- 
a

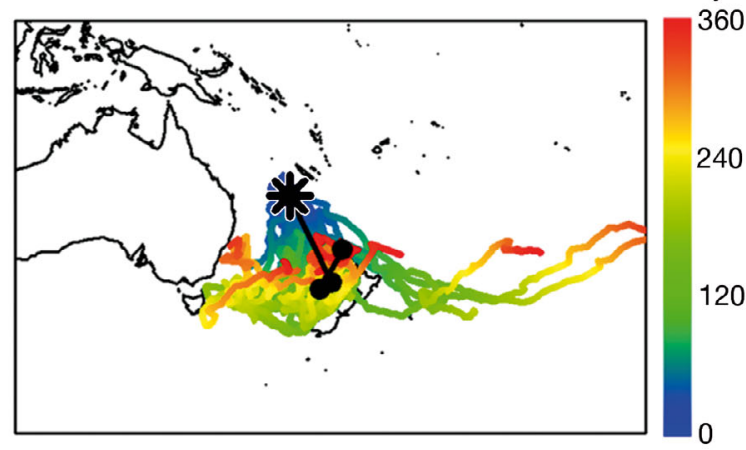

C

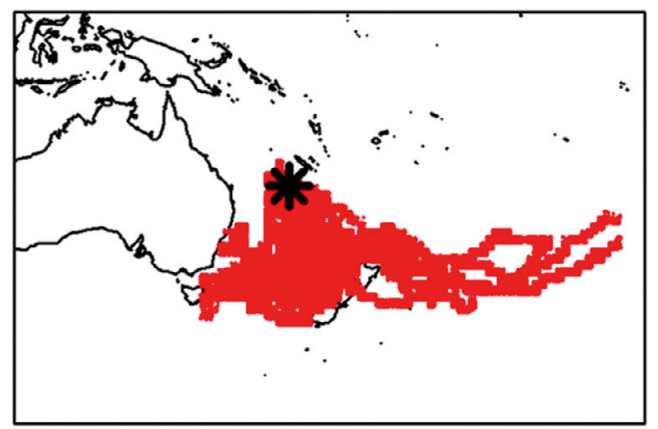

e
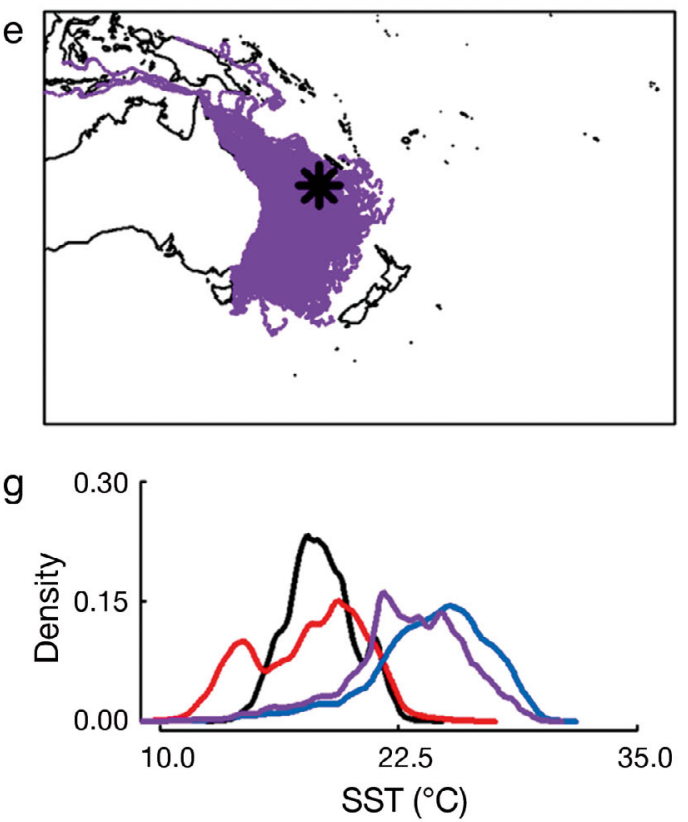

240

120
Days
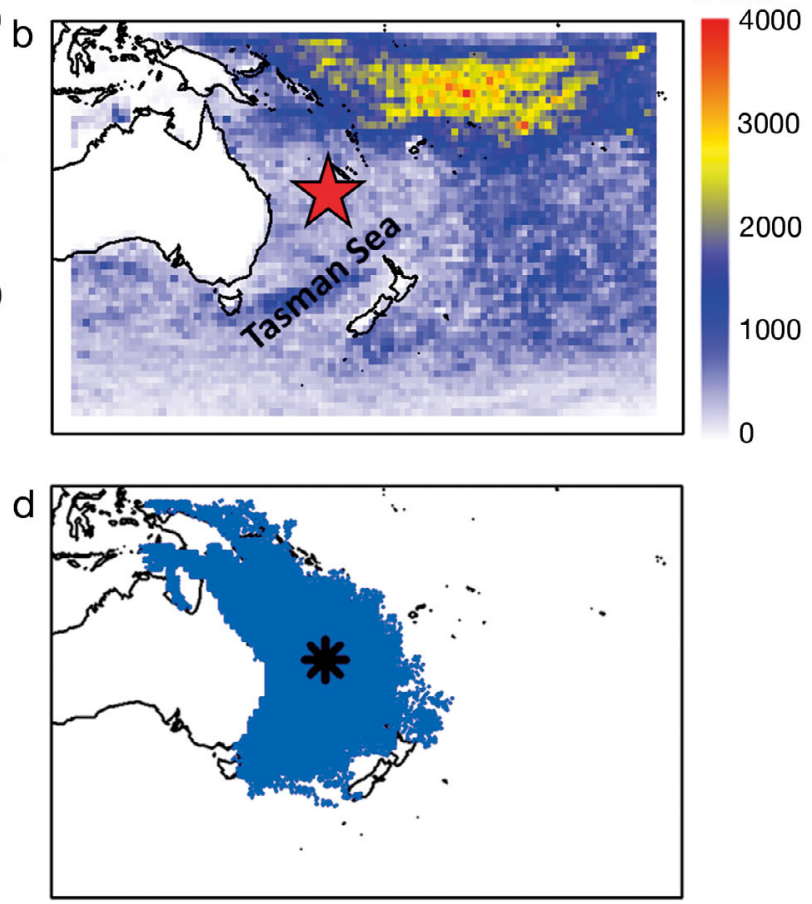

f

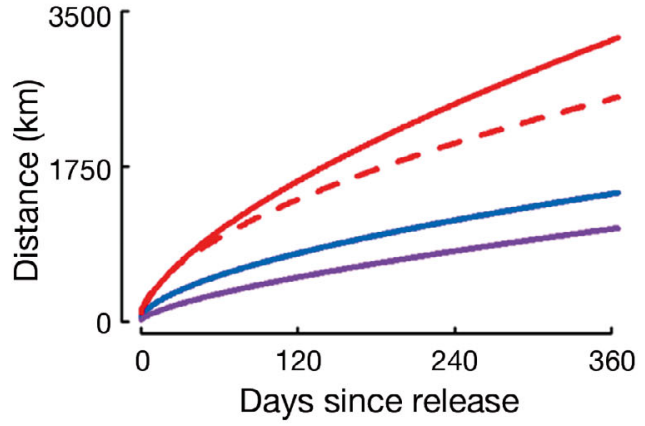

h

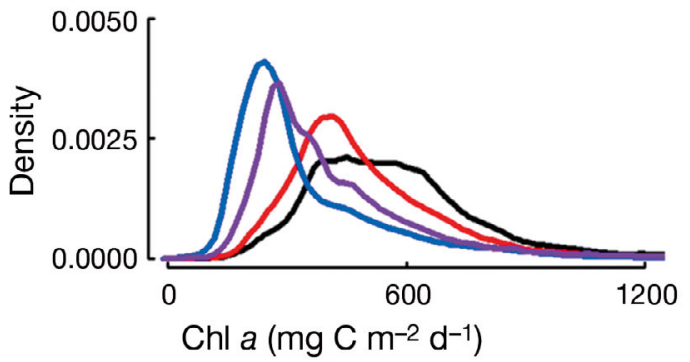

Fig. 1. Movement of juvenile loggerhead turtles Caretta caretta in relation to passive particles. (a) Interpolated real tracks of 46 juvenile loggerheads released southwest off New Caledonia on 21 September 2012. Black asterisk: release point (also in panels c-e); black solid line: median track for all the animals with each $120 \mathrm{~d}$ period marked by a black node. Colour indicates the day of tracking. (b) Number of Lagrangian drifters (indicated by colour scale) passing through each grid cell in the study area between 1980 and 2013. Red star: location of New Caledonia. (c-e) Cumulative distribution of 1000 simulated (c) turtle, (d) drifter and (e) HYCOM particles during one year of tracking. (f) Back-transformed fitted values of the distance between simulated turtle and passive (drifters and HYCOM) particles as a function of time since release. Solid and dashed red lines: average distance between simulated turtle and drifter particles, and simulated turtle and HYCOM particles, respectively; blue line: average distance among drifter particles; purple line: average distance among HYCOM particles. (g) Density distributions of sea surface temperature (SST) encountered by simulated turtle (red), drifter (blue) and HYCOM (purple) particles over 1 yr of simulations. Black: density distribution of SST encountered by the real turtle tracks in panel (a). (h) Density distributions of chl a concentration encountered by simulated turtle (red), drifter (blue) and HYCOM (purple) particles over 1 yr of simulations. Black: density distribution of chl a encountered by the real turtle tracks in panel (a) 
ticles (using the turtle probability matrix), released at the real turtle release site $\left(24.98^{\circ} \mathrm{S}, 163.03^{\circ} \mathrm{E}\right)$ and tracked over one year. We refer to these as 'simulated turtle tracks' as opposed to the 'real turtle tracks'. The simulated tracks were used in the subsequent testing of turtle movements against passive drift scenarios, so that the same number of turtle and passive particles could be released and compared. This approach further allowed particles to be released at several intervals along the trajectory of the real turtle track, to infer regional differences in the degree of directional swimming of juvenile turtles.

Along with the simulated turtle particles, 1000 drifter particles (based on the drifter probability matrix) were also released at the same location and tracked over the same time period. If a turtle or drifter particle during this time ended up in a grid cell which had no transition probabilities to other grid cells (an absorbent cell), that trajectory was terminated. ICHTHYOP v.2.21 particle-tracking software (Lett et al. 2008) was used to release 1000 virtual particles into HYCOM (http://hycom.org/) output on 21 September 2012 within a $1^{\circ} \times 1^{\circ}$ rectangle, centred on the release site of the turtles. For advection of particles through HYCOM velocity fields, ICHTHYOP implemented a Runge-Kutta 4th order time-stepping method whereby particle position was calculated each half-hour (Lett et al. 2008) and recorded every $6 \mathrm{~h}$.

At the end of the simulations, the resulting turtle, drifter and HYCOM trajectories were compared. The spatial overlap between simulated turtle and passive particles (drifter and HYCOM) was estimated, using the area of intersection (AI) approach (Fieberg \& Kochanny 2005), which provides a single measure of overlap between the $95 \%$ kernel utilization distributions of the turtle and the passive particles. AI ranges between 0 (no overlap between the turtle and passive particles utilization distributions) and 1 (the turtle and passive particles have identical utilization distributions). The in silico divergence rate between the simulated turtle and passive (drifter and HYCOM) particles was investigated by estimating the average distance between turtle and drifter particles, and between turtle and HYCOM particles, as a function of time since release, using linear regression models in R ( $\mathrm{R}$ Core Team 2014). The relationship between distance and time since release was nonlinear and was fitted after both variables were logtransformed. To be able to distinguish between active (turtle driven) and passive (current driven) divergence between particles, the average divergence rate between drifter particles (the drifterdrifter distance as a function of time since release) and the average divergence rate between HYCOM particles (the HYCOM-HYCOM distance as a function of time since release) were also calculated.

While the turtle transition matrix depicts the movement of turtles, which is a combination of physical processes and the swimming behaviour of the turtles (Fossette et al. 2012), the drifter and HYCOM models depict the movement attributable exclusively to physical processes. Owing to the pooling of drifter data across $30 \mathrm{yr}$, the drifters covered a wider range of oceanic conditions compared to those experienced by the tracked turtles. In contrast, HYCOM depicts ocean conditions during the same period in which turtles were tracked. Therefore, the drifter data constitute a broad range of ocean transport scenarios (high dispersion), some of which may not be directly relevant to the tracked turtles, whereas HYCOM will display a smaller range of ocean transport scenarios (low dispersion), but presumably those directly relevant to the tracked turtles. However, HYCOM is necessarily a simplification of ocean circulation and does not include all factors that contribute to the velocity of an object at the surface of the ocean (e.g. Stokes drift, tides). Thus divergence between turtle movements and drifter movements might be due to spatiotemporal mismatch in oceanic conditions, whereas divergence between turtle movements and HYCOM might be due to model error. By comparing our turtle tracks to both empirically derived and modelled passive particles that characterize long-term ocean velocity in this region (i.e. drifters) and the ocean current conditions that were predicted to exist during the tracking experiment (i.e. HYCOM) we were able to cross-validate our models (Fossette et al. 2012) and bracket the range of oceanic conditions likely experienced by tracked turtles.

\section{Spatial variations in directional movement}

The optimal movement strategy for an animal may change as the animal's journey progresses and the destination is approached (Chapman et al. 2011). To investigate the degree of active directional movement versus passive drifting for the juvenile turtles along their trajectory, simulated turtle and passive (drifter and HYCOM) particles were also released at regular intervals along the geographic median of the real turtle tracks (Fig. 1a), and the resulting trajectories were compared $100 \mathrm{~d}$ after each release. Release sites were positioned $120 \mathrm{~d}$ apart, starting from the real release date (Day 0), with the last release site being the median position of the real turtle tracks at 
Day 360. At each site, 100 turtle, 100 drifter and 100 HYCOM particles were released and tracked as described above. Again, the divergence rates between simulated turtle and drifter particles, and between turtle and HYCOM particles, were estimated for each release site and compared to the divergence rate between drifter particles and the divergence rate between HYCOM particles, respectively.

\section{Seasonal and yearly variations in ocean currents}

To investigate the potential effects of seasonal variation in ocean currents on the spatial overlap and divergence rate between simulated turtle and drifter particles, the drifter data set was subdivided into the 4 austral seasons: summer (December-February), autumn (March-May), winter (June-August) and spring (September-November) and the simulations described above were repeated for each season. To investigate yearly variations in ocean currents, the drifter data set was similarly subdivided into 4 time periods: Period 1 (1990-1995), Period 2 (1996-2001), Period 3 (2002-2007) and Period 4 (2008-2013), and the simulations were again repeated for each period. Although a comparison of drifter movement between individual years would have been more informative, the low number of drifters passing through the study area in a single year prevented this. Seasonal and yearly variations in ocean currents were not investigated for the HYCOM simulations as the reason for using that model was to represent the ocean conditions that existed as turtles were moving through those oceanic regions at those particular times.

\section{Sea-surface temperature and chlorophyll a}

Sea turtles are ectotherms, meaning that their body temperature, and hence basal metabolic rate, is strongly influenced by the surrounding sea temperature (Hochscheid et al. 2002, 2004, Southwood et al. 2003). Since metabolic rate influences growth and survival, remaining in a favourable temperature range is likely to provide direct benefits for turtles. The distribution of prey is another key factor influencing the movement of marine species (Sims et al. 2006). Oceanic juvenile loggerheads spend most of their time $(90 \%)$ in the upper $15 \mathrm{~m}$ of the water column (Howell et al. 2010) and are thought to be preying mostly on low trophic chain prey (neuston) that are either at or near the water surface (Boyle \& Limpus 2008). Since both primary and secondary produc- tivity will be affected by sea surface temperature (SST) and chlorophyll a (chl a) concentration (Strömberg et al. 2009), these 2 variables are likely to influence sea turtle movement and distribution (Etnoyer et al. 2006).

We compared the SST and chl a concentrations encountered by turtles and passive (drifter and HYCOM) particles in silico. SST data were obtained from the National Oceanic and Atmospheric Administration's (NOAA) National Climatic Data Center (NCDC) (www.ncdc.noaa.gov), at a temporal resolution of $1 \mathrm{~d}$ and a spatial grid resolution of $0.25^{\circ}$, covering the entire study area and tracking period. The SST data were estimated by NOAA using infrared satellite data from the Advanced Very High Resolution Radiometer (AVHRR) and in situ data from ships and buoys, using the optimum interpolation method described by Reynolds et al. (2007). Satellite-derived surface chl a pigment concentration data were obtained from the Oregon State University Ocean Productivity reanalysis dataset (www.science.oregonstate. edu/ocean.productivity/index.php), which is based on MODIS chl a and temperature data, Sea-viewing Wide Field-of-view Sensor (SeaWiFS) photosynthetically available radiation (PAR) (oceancolor.gsfc.nasa. gov/cms/atbd/par), and estimates of euphotic zone depth, using the Vertically Generalized Production Model as the algorithm (Behrenfeld \& Falkowski 1997). Chl a concentrations were obtained as $8 \mathrm{~d}$ averages and at a spatial grid resolution of $0.167^{\circ}$.

The distributions of SST and chl a values encountered by the simulated turtle, drifter and HYCOM particles were compared using 2-sided KolmogorovSmirnov (K-S) tests. The critical value of the Dstatistic for the K-S test, $\mathrm{D}_{\mathrm{KS}}$, was estimated based on the sample size of the simulations $(\mathrm{n}=1000)$ and a level of significance of $\alpha=0.05$, which corresponded to $\mathrm{D}_{\mathrm{KS}}=0.043$.

\section{RESULTS}

\section{In situ trajectories}

Location data of turtles were obtained from the tags for between 6 and $519 \mathrm{~d}$ (mean $=279$, median $=$ 250), resulting in a total of 12850 tracking days between 2012 and 2014, during which the turtles moved a cumulative distance of 196 to $10201 \mathrm{~km}$ $($ mean $=5550$, median $=5106)($ Table S1 in Supplement 1). The mean and median time period between 2 Argos locations was 26.9 and $9.6 \mathrm{~h}$, respectively. After being released, the turtles moved rapidly south 
towards the Tasman Sea area, located between New Zealand and Australia (Fig. 1a, Animations S1 \& S2 at www.int-res.com/articles/suppl/m557p247_supp/). After approximately $60 \mathrm{~d}$ the turtles reached the Tasman Sea, at which point their movement slowed down and became more sinuous. The spread of the turtles also increased after reaching the Tasman Sea. During the first half-year of tracking, the turtles were still slowly moving south within the Tasman Sea, however after this point their net movement shifted slightly northwards before the tracks ended (Fig. 1a, Animations S1 \& S2).

To construct the turtle transition probability matrix used for the model simulations, a total of 11502 turtle positions were used, covering 12850 tracking days. During this time, the turtles visited 566 (9.4\%) of the 6000 grid cells in the study area. From the grid cells visited, the mean \pm SD number of turtle positions was $20.3 \pm 31.1(\min .=1, \max .=402)$. To inform the transition probability matrix for the drifter data, 3716303 Lagrangian drifter positions were used, covering 927529 tracking days in total. Between 1980 and 2013 the drifters visited 5260 (87.7\%) of the 6000 grid cells in the study area. From the grid cells visited, each cell was visited by (mean \pm SD) $705 \pm 604$ drifter buoys (min. = 1, max. = 3902). Hence, the drifter data provided a good coverage of the study area (Fig. 1b).

The transition probability matrices showed that most transitions between grid cells occurred along the diagonal of the matrix (Fig. S1 in Supplement 1). This means that both turtles and drifters either stayed within the same grid cell or moved to a grid cell directly adjacent to the current grid cell, or to one of its diagonal neighbours, between time steps. No transitions were observed across 2 or more grid cells in a single time step. While the drifter data set covered transitions from all grid cells, the turtle transition matrix was limited to a fewer number of grid cells located near the centre of the study area (Fig. S1).

\section{In silico trajectories}

The simulated turtle and passive particles showed a clear difference in their trajectories (Fig. 1c-e, and Animation S3). Consistent with the real turtle tracks (Fig. 1a \& Animations S1 \& S2), the simulated turtle particles moved rapidly south towards the Tasman Sea after being released (Fig. 1c \& Animation S3). In contrast, most of the drifter particles moved west and northwest towards the Australian east coast (Fig. 1d \& Animation S3). The HYCOM particles were similarly distributed along the Australian east coast, as well as south, but to a lesser extent compared to the drifter particles (Fig. 1e \& Animation S3). One year into the simulations, the overlap of cumulative particle positions between the simulated turtles and the passive particles was only 14.5 and $20.0 \%$ (area of intersection), for drifter and HYCOM particles, respectively. At this point, both the drifter and HYCOM particles had spread all along the Australian east coast, whereas most of the simulated turtle particles were within the Tasman Sea area, with some turtle particles having moved east off $\mathrm{New}$ Zealand along the same latitude (Fig. 1c-e \& Animation S3).

The rate of divergence between simulated turtle and drifter particles (the slopes of the solid red line in Fig. 1f \& black line in Fig. S2a in Supplement 1) was significantly higher than the divergence rate among drifter particles (the slopes of the blue line in Fig. 1f \& black line in Fig. S2b) $(t=-35.8, \mathrm{p}<0.001$, Table S2 in Supplement 1). The HYCOM simulations showed similar results, with the rate of divergence between turtle and HYCOM particles (the slopes of the dashed red line in Fig. 1f \& black line in Fig. S2c) being significantly higher than the divergence rate among HYCOM particles (the slope of the purple line in Fig. 1f and black line in Fig. S2d) $(t=68.7, \mathrm{p}<$ 0.001 , Table S2). The full model (Table S2) explained $55.0 \%\left(\mathrm{R}^{2}\right)$ of the variance in distance between particles. The divergence rate between particles (the slopes of the lines in Fig. 1f \& Fig. S2) was always higher at the beginning of the trajectories, but decreased as the number of days since release increased (Fig. 1f \& Fig. S2).

\section{Spatial variations in directional movement}

The rate of divergence between simulated turtle and passive particles (drifters and HYCOM) varied across the trajectory of the turtles (Figs. $2 \& 3$ ). The divergence rate was highest between turtle and passive particles released at Day 0 , as the simulated turtles moved directly south from their real release site down towards the Tasman Sea area, in a direction more or less opposite to that of the ocean currents (i.e. drifters and HYCOM particles). Turtle particles released at the other 3 simulated release sites (Days 120, 240 and 360), all within the Tasman Sea area, showed less divergence from the simulated passive particles (drifter and HYCOM); suggesting more similar movement of simulated turtles and passive particles in this region (Figs. $2 \& 3$ ). In support of this, the area of intersection between the 
simulated turtle and drifter particles after $100 \mathrm{~d}$ was greatest for release sites in the Tasman Sea $\left(\mathrm{AI}_{\mathrm{D} 0}=\right.$ $27.2 \%, \mathrm{AI}_{\mathrm{D} 120}=56.8 \%, \mathrm{AI}_{\mathrm{D} 240}=56.0 \%, \mathrm{AI}_{\mathrm{D} 360}=$ $44.9 \%$ ). Likewise, the areas of intersection between simulated turtle and HYCOM particles were also greatest in the southern Tasman Sea, though in some cases distributions of HYCOM particles and simulated turtles were quite different and swimming by turtles in this region cannot entirely be ruled out $\left(\mathrm{AI}_{\mathrm{D} 0}=22.5 \%, \mathrm{AI}_{\mathrm{D} 120}=21.8 \%, \mathrm{AI}_{\mathrm{D} 240}=57.3 \%\right.$, $\left.\mathrm{AI}_{\mathrm{D} 360}=27.3 \%\right)$.

\section{Seasonal and yearly variations in ocean currents}

The in silico drifter particles showed small seasonal variation in their trajectories (Fig. S3 in Supplement 1). Ocean currents were similar in summer, autumn and spring, with drifters distributing themselves along most of the Australian east coast. In winter, however, the majority of drifters travelled offshore along the northeastern coast of Australia, with only a few drifters travelling south (Fig. S3). Similarly, there was not much yearly variation in ocean
Day
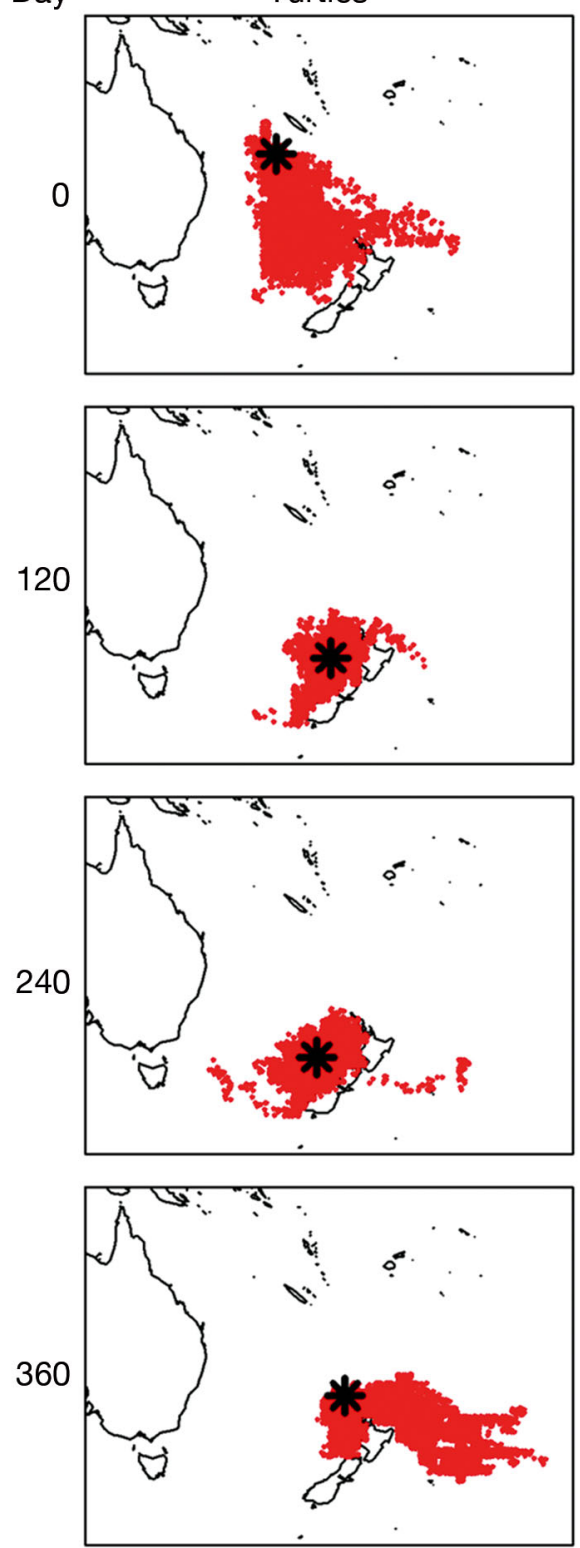

Drifters
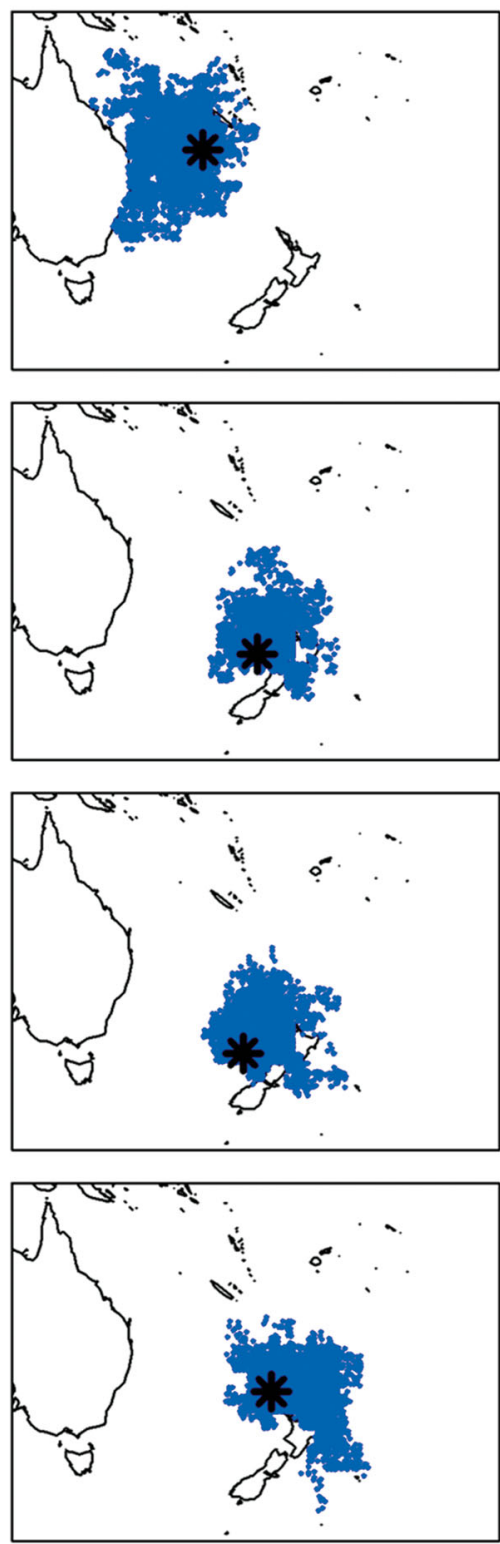

HYCOM
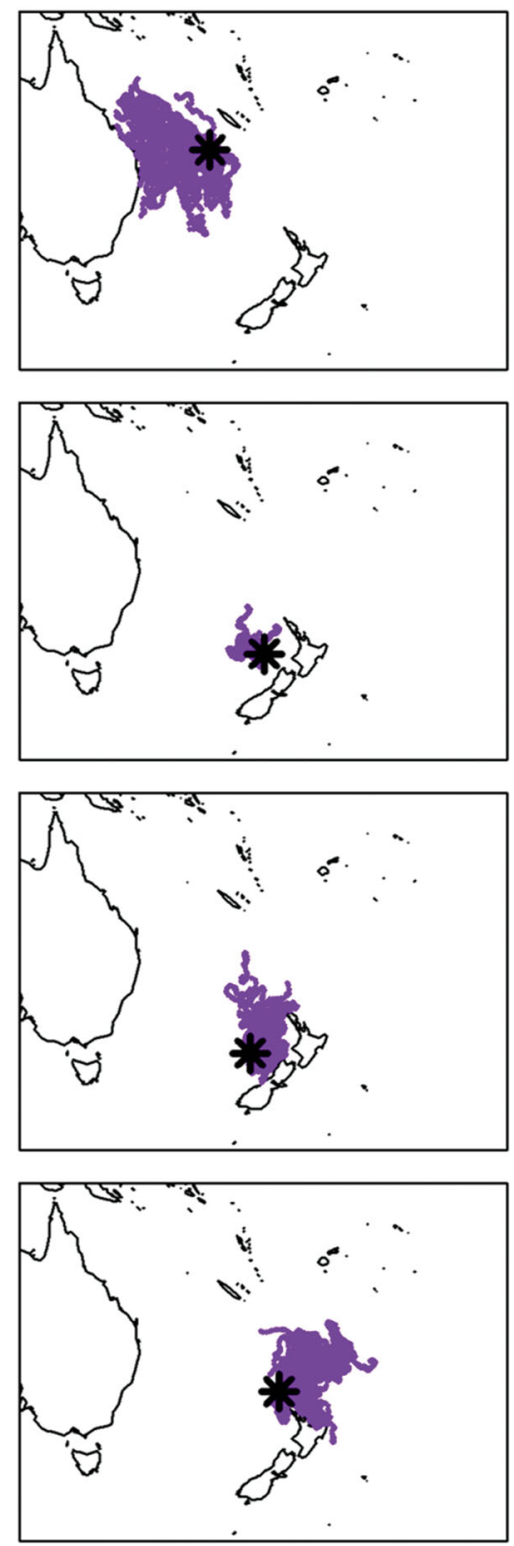

Fig. 2. Cumulative distributions of 100 simulated turtle (red), drifter (blue) and HYCOM (purple) particles released at different locations (black asterisks) along the trajectory (every $120 \mathrm{~d}$, at Days 0, 120, 240, 360) of the real turtle track (see Fig. 1a). The duration of each simulated track was $100 \mathrm{~d}$ 
currents, with drifters from all time periods distributing themselves along most of the Australian east coast (Fig. S4 in Supplement 1). The only deviances were in Period 1, when most drifters ended up in the northeastern part of Australia and none moved into the Tasman Sea area, and in Period 2, when the drifters travelled mainly along the southeastern Australian coast and in the northern parts of the Tasman Sea (Fig. S4). There was a small overlap between the simulated turtles and drifters particles irrespective of season $\left(\mathrm{AI}_{\text {summer }}=13.8 \%, \mathrm{n}=940263 ; \mathrm{AI}_{\text {autumn }}=\right.$ $10.9 \%, \mathrm{n}=966648 ; \mathrm{AI}_{\text {winter }}=10.7 \%, \mathrm{n}=922994$; a) Divergence rate
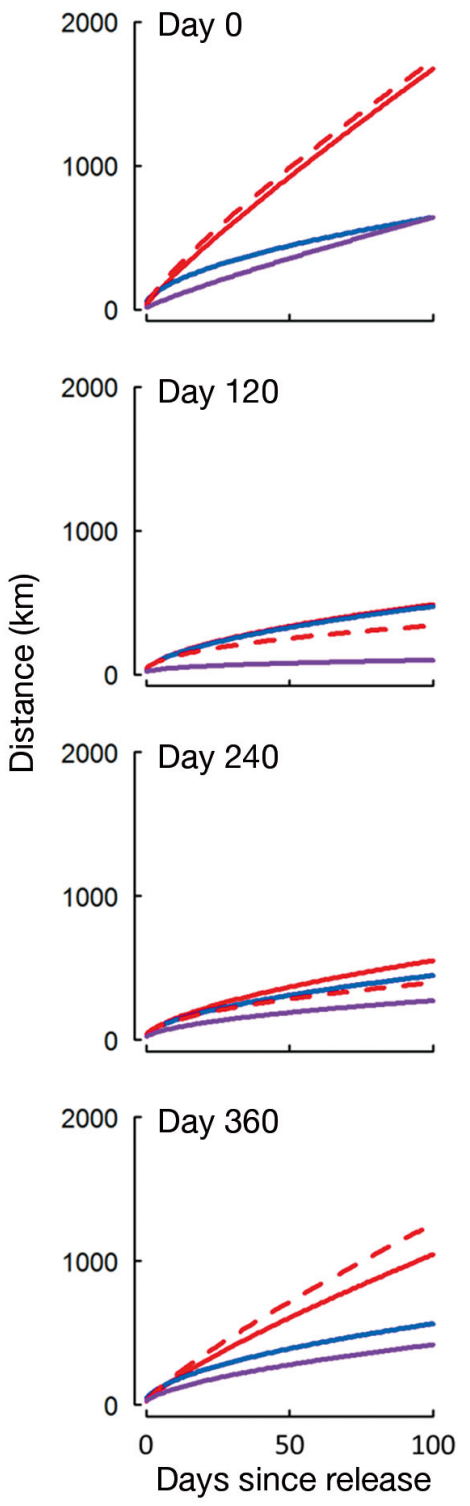

b) SST
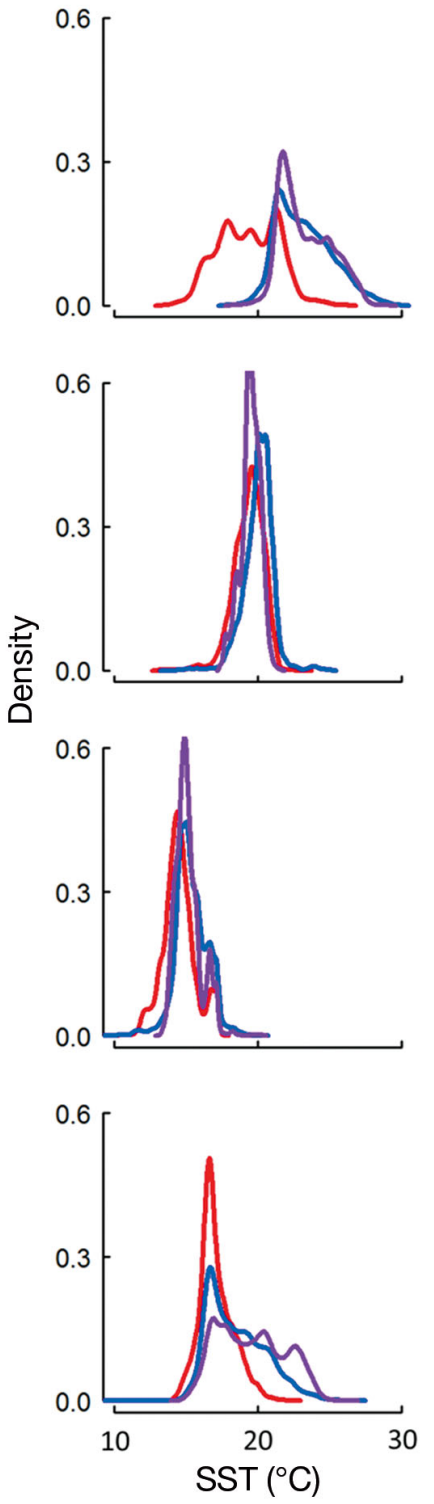

c) Chl a
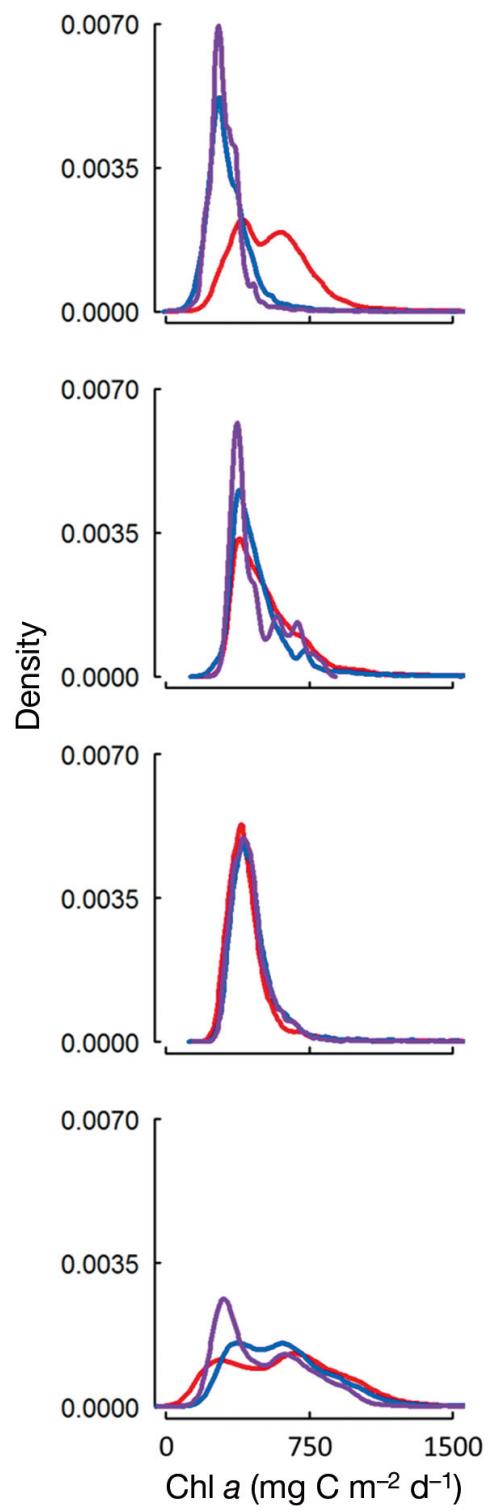

Fig. 3. Differences in divergence rates, SST and chl a concentrations encountered between 100 simulated turtle and passive (drifters and HYCOM) particles released at different locations along the trajectory (every 120 d, at Days 0, 120, 240 and 360) of the geographic median of real turtle tracks (see Fig. 1a). The duration of each simulated track was 100 d. (a) Back-transformed fitted values of the distance between simulated turtle and passive (drifters and HYCOM) particles as a function of time since release; solid and dashed red lines: average distance between simulated turtle and drifter particles, and simulated turtle and HYCOM particles, respectively; blue line: average distance among drifter particles; purple line: average distance among HYCOM particles. (b) Density distributions of sea surface temperature (SST) encountered by simulated turtle (red), drifter (blue) and HYCOM (purple) particles. (c) Density distributions of chl a concentrations encountered by simulated turtle (red), drifter 
$\left.\mathrm{AI}_{\text {spring }}=17.6 \%, \mathrm{n}=886398\right)$ and time period $\left(\mathrm{AI}_{\text {Period1 }}=7.6 \%, \mathrm{n}=537230 ; \mathrm{AI}_{\text {Period } 2}=24.3 \%, \mathrm{n}=\right.$ $725319 ; \mathrm{AI}_{\text {Period } 3}=11.2 \%, \mathrm{n}=1204671 ; \mathrm{AI}_{\text {Period } 4}=$ $20.5 \%, \mathrm{n}=1152444$ ). For all seasons and time periods, the rate of divergence (the slopes of the lines in Fig. S5 in Supplement 1) between simulated turtle and drifter particles was significantly higher than between drifter particles (Fig. S5). Our results were hence robust to seasonal and yearly variations in ocean currents.

\section{Sea-surface temperature and chlorophyll a}

The SSTs encountered by the simulated particles differed significantly between turtles and drifters $\left(D_{\mathrm{KS}}=0.760, \mathrm{p}<0.001\right)$ and between turtles and HYCOM particles $\left(\mathrm{D}_{\mathrm{KS}}=0.664, \mathrm{p}<0.001\right)$ (Fig. 1g). Consistent with the SST encountered by the real turtle tracks $\left(18.5 \pm 1.8^{\circ} \mathrm{C}, \min .=13.0, \max .=24.3\right.$, Animation S1), most simulated turtle particles experienced relatively lower $\mathrm{SST}\left(17.8 \pm 2.9^{\circ} \mathrm{C}\right.$, min. $=$ 9.0, $\max .=27.0$ ) compared to the drifter and HYCOM particles, which spread across a wider range of latitudes and on average experienced higher SST (Drifter: $24.2 \pm 3.1^{\circ} \mathrm{C}, \min .=9.6, \max .=$ 31.2; HYCOM: $23.0 \pm 3.1^{\circ} \mathrm{C}$, min. $=9.0, \max .=30.5$ ) (Fig. 1g).

The chl a concentrations encountered by the simulated particles also differed significantly between turtles and drifters $\left(\mathrm{D}_{\mathrm{KS}}=0.459, \mathrm{p}<0.001\right)$ and between turtles and HYCOM particles $\left(\mathrm{D}_{\mathrm{KS}}=0.270, \mathrm{p}<\right.$ 0.001) (Fig. 1h). Both the real $\left(578 \pm 244 \mathrm{mg} \mathrm{C} \mathrm{m}^{-2}\right.$ $\mathrm{d}^{-1}$, median $=543, \min .=115, \max .=4432$, Anima tion S2) and simulated turtles $\left(500 \pm 223 \mathrm{mg} \mathrm{C} \mathrm{m}^{-2}\right.$ $\mathrm{d}^{-1}$, median $\left.=453, \min .=23, \max .=7810\right)$ encountered higher chl a concentrations compared to the simulated drifter $\left(370 \pm 286 \mathrm{mg} \mathrm{C} \mathrm{m}^{-2} \mathrm{~d}^{-1}\right.$, median $=$ 284, min. = 21, max. = 9250) and HYCOM particles $\left(446 \pm 342 \mathrm{mg} \mathrm{C} \mathrm{m}^{-2} \mathrm{~d}^{-1}\right.$, median $=360, \mathrm{~min} .=27$, max. $=9250)$ (Fig. 1h).

The overlap in SST and chl a concentration encountered between the simulated turtle and passive (drifter and HYCOM) particles varied along the trajectory of the turtles (Fig. 3). Consistent with the fullyear simulations (Fig. 1), the simulated turtle particles released on Day 0 experienced lower SST and higher chl a concentrations on average compared to the passive particles. Simulated turtle particles released further down the trajectory of the real turtle tracks (Days 120, 240 and 360) experienced similar SST and chl a concentrations to the passive particles (Fig. 3).

\section{DISCUSSION}

This study shows, at the scale of an entire ocean basin, that juvenile turtles display directional movement beyond what would be expected based on ocean currents alone. Our conclusions are based on the comparison of simulated juvenile turtle tracks (modelled from real turtle tracks) with 2 different ocean current models to allow cross-validation. By modelling the movement of turtles and ocean currents, we were able to simulate the release of turtles at different sites within our study area and compare their trajectories to simultaneously released passive particles in order to assess spatial variations in directional movement of juvenile turtles. This would not have been possible through a simple qualitative analysis of the raw turtle tracks.

The rate of divergence between simulated turtle and passive particles varied across the trajectory of the turtles, suggesting that directional swimming by turtles varied regionally. After release, all of the tracked turtles showed a strong directional movement south towards the Tasman Sea area. The consistency in movement between the real turtle tracks and the high divergence rate between the simulated turtles and the passive particles suggest that the turtles were swimming actively against the currents to reach the Tasman Sea area. Within the Tasman Sea, the divergence between simulated turtles and passive particles was less pronounced, which suggests that directional movement in this region might be largely attributable to ocean currents. This movement pattern is consistent with stranding records of young loggerhead sea turtles in the Southwest Pacific, which shows that posthatchling loggerhead turtles of similar size do not occur along the east Australian coastline (Boyle et al. 2009). Within the Tasman Sea area lies the Tasman Front, a major oceanographic feature and an important foraging habitat for pelagic fish and larvae (Mullaney et al. 2014). Our tracking data and simulations suggest that this area might also be a suitable foraging habitat for juvenile loggerheads, with a reduction in directional swimming resulting in the turtles moving in tandem with their prey (i.e. neuston), and potential flotsam habitats, which drift passively (Witherington et al. 2012, Mansfield et al. 2014). Consistent with this hypothesis, we found that simulated turtles were distributed in more productive, and also more pelagic, areas (higher chl $a$, appropriate temperature range) than what would be expected if their movement depended on passive transport only. Hence, this apparent behav- 
ioural 'switch' is consistent with the hypothesis that directional locomotion is reduced in favourable oceanic areas (Putman et al. 2015). Had the turtles been drifting passively, our models predict that a high proportion of them would have ended up in east Australian coastal waters, which is not supported by stranding data in this region (Boyle et al. 2009). This study also adds support to the hypothesis that self-recruitment in marine systems that are physically open for a species relies on the behaviour (i.e. directional swimming) of the species (Wolanski 2016).

Although the tracked turtles in this study aggregated in the Tasman Sea, whether or not this area constitutes a foraging ground for wild loggerheads of similar size is unknown. While similar sized loggerhead turtles can be found off the coasts of Chile and Peru in the Southeast Pacific, this size class is not commonly seen off the coast of east Australia, west coast of New Zealand or in the Tasman Sea (Boyle et al. 2009). The same is true for the release site south of New Caledonia, where similar-sized loggerhead turtles are seldom found. Further, the few naturally occurring loggerhead turtles of similar size found in this region did not originate from the Southwestern Pacific genetic stock (C. J. Limpus pers. comm.). The lack of similar sized loggerheads in the region could also be caused by size differences between similarly aged captive and wild loggerheads. The captive reared turtles in this study were only 1 yr 7 mo old at the time of release. Wild loggerheads of similar size $(\sim 35 \mathrm{~cm}$ straight carapace length) are more likely to be around 6 yr old (Zug et al. 1995). At this age the turtles could have moved far from the Tasman Sea, potentially following prevailing ocean currents moving eastwards towards South America (Naro-Maciel et al. 2014). Hence, while our experimental design was appropriate to test our hypotheses relating to directional movement in juvenile sea turtles, it was not intended to describe the movement of naturally occurring smaller post-hatchling turtles in this region. It is also worth noting that the juvenile turtles in this study represent a restricted size class $(\sim 35 \mathrm{~cm})$, which might not represent the behaviour of other size classes of juvenile loggerhead turtles.

The growth and survival of sea turtles is likely determined by prey availability and, as subtropical ectotherms, the temperature of the surrounding waters (Mansfield \& Putman 2013). Greater food availability (i.e. neuston) for turtles is likely correlated with greater chl a concentration (Etnoyer et al. 2006, Strömberg et al. 2009). Both the real and simu- lated turtles encountered higher chl a concentrations compared to the passive particles. This suggest that through directional swimming, young sea turtles are able to reach more favourable developmental habitats, which are likely to benefit their growth and survival, and consequently their fitness. Directional swimming also resulted in juvenile loggerheads ending up in relatively narrow temperature ranges of cooler water. Whether the cooler SST encountered is a side effect of this movement pattern (turtles seeking more productive waters), or if it reduces metabolic costs of the turtles, remains to be investigated. Although feeding rates of turtles generally decrease at colder temperatures (Moon et al. 1997, Hochscheid et al. 2004), the higher food availability (i.e. higher chl a concentrations) might compensate for this. Moreover, extended periods at the surface can significantly increase the temperatures experienced by young turtles beyond satellite-derived measures of SST (Mansfield et al. 2014).

Some migrants moving in environments where they can perceive fixed reference points (e.g. birds flying over land) can detect lateral deflections caused by environmental flows (winds, currents) and compensate accordingly (Chapman et al. 2011). In contrast, sea turtles in the open ocean far from land are not thought to be able to directly sense currents because of the absence of fixed reference points. Instead, the most parsimonious explanation for our finding that naïve juvenile loggerheads demonstrate directional swimming, is that they are using some sort of innate regional navigational markers (Lohmann et al. 2001) rather than responding to the current directly. Furthermore, the hypothesis for use of the Earth's geomagnetic field as a crude map, which is founded in thorough experimental evidence (Lohmann \& Lohmann 1994, Lohmann et al. 2001, 2004, Luschi et al. 2007, Putman et al. 2011), is consistent with the geographical extent of the inferred feeding grounds being relatively large, since even low resolution geomagnetic navigation would be sufficient for the animals to successfully locate these areas (Lohmann et al. 2004, Gould 2014).

In summary, we have shown that young loggerhead sea turtles on their first travels across an ocean basin show regionally tuned directional swimming. Our findings provide a valuable contribution to the growing amount of evidence of directional movement in young sea turtles (Lohmann \& Lohmann 1994, Lohmann et al. 2001, 2004, Putman et al. 2011, Putman \& Mansfield 2015), and further shows that this movement strategy can be used by juvenile sea turtles to reach more favourable oceanic habitats. 
Acknowledgements. We thank E. van Sebille and D. R. Kobayashi for helpful discussions during analyses. We thank L. Jim and the students from the Hawaii Preparatory Academy for help in the field. We thank K. Frutchey and R. Clarke of the Pacific Islands Regional Office, NMFS, NOAA for providing funding. Support for N.F.P. was provided by the NOAA Atlantic Oceanographic \& Meteorological Laboratory. The animals used in this study were raised in captivity under permits from the New Caledonia government for the conduction of this experiment (permit 3189-2010/ARR/ DENV issued 31 December 2010). All applicable government rules for proper sea turtle care and humane treatment were followed (no animals were sacrificed). We thank C. J. Limpus and 2 anonymous reviewers for their constructive comments, which helped to improve this manuscript. G.C.H. and F.C. formulated this study. G.H.B. conceived the turtle tracking project and coordinated the fieldwork, M.R.R. coordinated and performed the field work and D.M.P. assembled the turtle tracking data. F.C., N.F.P. and G.C.H. led the data analysis and writing. Other authors contributed to manuscript drafts.

\section{LITERATURE CITED}

Abecassis M, Senina I, Lehodey P, Gaspar P, Parker D, Balazs G, Polovina J (2013) A model of loggerhead sea turtle (Caretta caretta) habitat and movement in the oceanic North Pacific. PLOS ONE 8:e73274

> Åkesson S, Hedenström A (2007) How migrants get there: migratory performance and orientation. Bioscience 57: 123-133

> Alerstam T, Hedenström A, Åkesson S (2003) Long-distance migration: evolution and determinants. Oikos 103: 247-260

> Behrenfeld MJ, Falkowski PG (1997) Photosynthetic rates derived from satellite-based chlorophyll concentration. Limnol Oceanogr 42:1-20

Bleck R (2002) An oceanic general circulation model framed in hybrid isopycnic-Cartesian coordinates. Ocean Model 4:55-88

Boyle MC, Limpus CJ (2008) The stomach contents of posthatchling green and loggerhead sea turtles in the southwest Pacific: an insight into habitat association. Mar Biol 155:233-241

> Boyle MC, Fitzsimmons NN, Limpus CJ, Kelez S, VelezZuazo X, Waycott M (2009) Evidence for transoceanic migrations by loggerhead sea turtles in the southern Pacific Ocean. Proc R Soc B 276:1993-1999

- Chapman JW, Klaassen RHG, Drake VA, Fossette S and others (2011) Animal orientation strategies for movement in flows. Curr Biol 21:R861-R870

> Chassignet EP, Hurlburt HE, Smedstad OM, Halliwell GR and others (2007) The HYCOM (HYbrid Coordinate Ocean Model) data assimilative system. J Mar Syst 65: 60-83

> Dingle H, Drake VA (2007) What is migration? Bioscience 57:113-121

Etnoyer P, Canny D, Mate BR, Morgan LE, Ortega-Ortiz JG, Nichols WJ (2006) Sea-surface temperature gradients across blue whale and sea turtle foraging trajectories off the Baja California Peninsula, Mexico. Deep-Sea Res II 53:340-358

> Fieberg J, Kochanny CO (2005) Quantifying home-range overlap: the importance of the utilization distribution.
J Wildl Manag 69:1346-1359

Fossette S, Putman NF, Lohmann KJ, Marsh R, Hays GC (2012) A biologist's guide to assessing ocean currents: a review. Mar Ecol Prog Ser 457:285-301

> Gould JL (2014) Animal navigation: a map for all seasons. Curr Biol 24:R153-R155

> Hays GC, Scott R (2013) Global patterns for upper ceilings on migration distance in sea turtles and comparisons with fish, birds and mammals. Funct Ecol 27:748-756

> Hays GC, Akesson S, Broderick AC, Glen F, Godley BJ, Papi F, Luschi P (2003) Island-finding ability of marine turtles. Proc R Soc B 270:S5-S7

Hays GC, Fossette S, Katselidis KA, Mariani P, Schofield G (2010) Ontogenetic development of migration: Lagrangian drift trajectories suggest a new paradigm for sea turtles. J R Soc Interface 7:1319-1327

> Hays GC, Mortimer JA, Ierodiaconou D, Esteban N (2014) Use of long-distance migration patterns of an endangered species to inform conservation planning for the world's largest marine protected area. Conserv Biol 28:1636-1644

Hein AM, Hou C, Gillooly JF (2012) Energetic and biomechanical constraints on animal migration distance. Ecol Lett 15:104-110

Hochscheid S, Bentivegna F, Speakman JR (2002) Regional blood flow in sea turtles: implications for heat exchange in an aquatic ectotherm. Physiol Biochem Zool 75:66-76

Hochscheid S, Bentivegna F, Speakman JR (2004) Longterm cold acclimation leads to high Q10 effects on oxygen consumption of loggerhead sea turtles Caretta caretta. Physiol Biochem Zool 77:209-222

> Howell EA, Dutton PH, Polovina JJ, Bailey H, Parker DM, Balazs GH (2010) Oceanographic influences on the dive behavior of juvenile loggerhead turtles (Caretta caretta) in the North Pacific Ocean. Mar Biol 157:1011-1026

> Kobayashi DR, Farman R, Polovina JJ, Parker DM, Rice M, Balazs GH (2014) 'Going with the flow' or not: evidence of positive rheotaxis in oceanic juvenile loggerhead turtles (Caretta caretta) in the south Pacific Ocean using satellite tags and ocean circulation data. PLOS ONE 9: e103701

> Lett C, Verley P, Mullon C, Parada C, Brochier T, Penven P, Blanke B (2008) A Lagrangian tool for modelling ichthyoplankton dynamics. Environ Model Softw 23:1210-1214

Lohmann KJ, Lohmann CMF (1994) Detection of magnetic inclination angle by sea turtles: a possible mechanism for determining latitude. J Exp Biol 194:23-32

Lohmann KJ, Cain SD, Dodge SA, Lohmann CMF (2001) Regional magnetic fields as navigational markers for sea turtles. Science 294:364-366

Lohmann KJ, Lohmann CMF, Ehrhart LM, Bagley DA, Swing T (2004) Geomagnetic map used in sea-turtle navigation. Nature 428:909-910

Lohmann KJ, Putman NF, Lohmann CMF (2012) The magnetic map of hatchling loggerhead sea turtles. Curr Opin Neurobiol 22:336-342

> Luschi P, Hays GC, Papi F (2003) A review of long-distance movements by marine turtles, and the possible role of ocean currents. Oikos 103:293-302

Luschi P, Benhamou S, Girard C, Ciccione S, Roos D, Sudre J, Benvenuti S (2007) Marine turtles use geomagnetic cues during open-sea homing. Curr Biol 17:126-133

Mansfield KL, Putman NF (2013) Oceanic habits and habitats-Caretta caretta. In: Wyneken J, Lohmann KJ, Musick JA (eds) Biology of sea turtles, Vol. 3 CRC Press, p 189-205 
Mansfield KL, Wyneken J, Porter WP, Luo J (2014) First satellite tracks of neonate sea turtles redefine the 'lost years' oceanic niche. Proc R Soc B 281:20133039

Moon DY, MacKenzie DS, Owens DWM (1997) Simulated hibernation of sea turtles in the laboratory: I. Feeding, breathing frequency, blood $\mathrm{pH}$, and blood gases. J Exp Zool 278:372-380

Mullaney TJ, Gillanders BM, Heagney EC, Suthers IM (2014) Entrainment and advection of larval sardine, Sardinops sagax, by the East Australian Current and retention in the western Tasman Front. Fish Oceanogr 23:554-567

Naro-Maciel E, Gaughran SJ, Putman NF, Amato G and others (2014) Predicting connectivity of green turtles at Palmyra Atoll, central Pacific: a focus on mtDNA and dispersal modelling. J R Soc Interface 11:201330888

Polovina J, Uchida I, Balazs G, Howell EA, Parker D, Dutton $P$ (2006) The Kuroshio Extension Bifurcation Region: A pelagic hotspot for juvenile loggerhead sea turtles. Deep-Sea Res II 53:326-339

Putman NF, He R (2013) Tracking the long-distance dispersal of marine organisms: sensitivity to ocean model resolution. J R Soc Interface 10:20120979

Putman NF, Mansfield KL (2015) Direct evidence of swimming demonstrates active dispersal in the sea turtle 'lost years'. Curr Biol 25:1221-1227

Putman NF, Endres CS, Lohmann CMF, Lohmann KJ (2011) Longitude perception and bicoordinate magnetic maps in sea turtles. Curr Biol 21:463-466

Putman NF, Verley P, Shay TJ, Lohmann KJ (2012) Simulating transoceanic migrations of young loggerhead sea turtles: merging magnetic navigation behavior with an ocean circulation model. J Exp Biol 215:1863-1870

Putman NF, Scanlan MM, Billman EJ, O'Neil JP and others (2014) An inherited magnetic map guides ocean navigation in juvenile Pacific salmon. Curr Biol 24:446-450

Putman NF, Verley P, Endres CS, Lohmann KJ (2015) Magnetic navigation behavior and the oceanic ecology of young loggerhead sea turtles. J Exp Biol 218:1044-1050

R Core Team (2014) R: A language and environment for sta-

Editorial responsibility: Peter Corkeron,

Woods Hole, Massachusetts, USA tistical computing. R Foundation for Statistical Computing, Vienna

Reynolds RW, Smith TM, Liu C, Chelton DB, Casey KS, Schlax MG (2007) Daily high-resolution-blended analyses for sea surface temperature. J Clim 20:5473-5496

Scott R, Marsh R, Hays GC (2012) A little movement orientated to the geomagnetic field makes a big difference in strong flows. Mar Biol 159:481-488

Scott R, Biastoch A, Roder C, Stiebens VA, Eizaguirre C (2014) Nano-tags for neonates and ocean-mediated swimming behaviours linked to rapid dispersal of hatchling sea turtles. Proc R Soc B 281:20141209

Sims DW, Witt MJ, Richardson AJ, Southall EJ, Metcalfe JD (2006) Encounter success of free-ranging marine predator movements across a dynamic prey landscape. Proc R Soc B 273:1195-1201

Southwood AL, Darveau CA, Jones DR (2003) Metabolic and cardiovascular adjustments of juvenile green turtles to seasonal changes in temperature and photoperiod. J Exp Biol 206:4521-4531

Strömberg KHP, Smyth TJ, Allen JI, Pitois S, O'Brien TD (2009) Estimation of global zooplankton biomass from satellite ocean colour. J Mar Syst 78:18-27

van Sebille E (2014) Adrift.org.au - a free, quick and easy tool to quantitatively study planktonic surface drift in the global ocean. J Exp Mar Biol Ecol 461:317-322

Wehner R (2003) Desert ant navigation: how miniature brains solve complex tasks. J Comp Physiol A Neuroethol Sens Neural Behav Physiol 189:579-588

> Witherington B, Hirama S, Hardy R (2012) Young sea turtles of the pelagic Sargassum-dominated drift community: habitat use, population density, and threats. Mar Ecol Prog Ser 463:1-22

Wolanski E (2016) Bounded and unbounded boundaries untangling mechanisms for estuarine-marine ecological connectivity: scales of $\mathrm{m}$ to $10,000 \mathrm{~km}$ - a review. Estuar Coast Shelf Sci (in press), doi:10.1016/j.ecss.2016.06.022

Zug GR, Balazs GH, Wetherall JA (1995) Growth in juvenile loggerhead seaturtles (Caretta caretta) in the North Pacific pelagic habitat. Copeia 1995(2):484-487

Submitted: June 27, 2016; Accepted: August 15, 2016

Proofs received from author(s): September 12, 2016 